\title{
C1q Production by Bone Marrow Stromal Cells
}

\section{To the Editor}

Complement components and their receptors have recently come into focus as key regulators in the clearance of apoptotic cells by human dendritic cells (DC), a subset of phagocytic cells derived from bone marrow stromal cell progenitors $[1,2]$. C1q, the first component of the classical pathway of complement activation, is able to bind to the surface of apoptotic cells inducing $\mathrm{C} 3 \mathrm{~b}$ deposition and promoting the uptake of apoptotic cells by $\mathrm{DC}$ via the interaction with $\mathrm{C} 1 \mathrm{q}$ receptor and other C1q binding structures (Table 1) [3]. C1q production by human DC has been reported to be restricted to immature DC in vitro, as it is downregulated upon DC maturation [4]. In human bone marrow, active phagocytosis of apoptotic cells and uptake of immune complexes, as well as antigen presentation to lymphocytes, are provided by stromal cells with dendritic morphology that are intermingled with haematopoietic cells. These cells, hereafter referred to as bone marrow stromal DC, contribute to the formation of the bone marrow microenvironment actively participating into the normal haematopoiesis through the constitution of maturational niches [5]. They also have a share in the composition of the bone marrow infiltrates in lymphoid malignancies, although the underlying mechanisms are still unknown [6]. We investigated the expression of $\mathrm{Clq}$ in bone marrow stromal cells ex vivo studying 17 bone marrow biopsies with normal histology or non-specific reactive changes by immunohistochemistry and fluorescent in situ bybridization (FISH). By immunohistochemical evaluation, $\mathrm{Clq}$ resulted strongly expressed by bone marrow stromal DC (Fig. 1A) and by macrophages (Fig. 1B) in all cases. These results were confirmed by double stainings with CD1a (Fig. 1A, inset) and CD68 (Fig. 1B, inset). FISH for C1q B chain mRNA confirmed that $\mathrm{C} 1 \mathrm{q}$ expression in bone marrow stromal cells was due to direct production of $\mathrm{C} 1 \mathrm{q}$ and not to $\mathrm{C} 1 \mathrm{q}$ uptake (Fig. 1C). Recently, a report by Yamada et al. [7] demonstrated that C1q was able to suppress pro-inflammatory cytokine production (IL12p40, TNF- $\alpha$ ) by murine bone marrow-derived DC in vivo. This

Table $1 \mathrm{C} 1 \mathrm{q}$ binding structures and their functions.

\begin{tabular}{ll}
\hline Receptor & Function \\
\hline $\begin{array}{l}\text { CR1 (CD35) } \\
\text { Calreticulin (CD91, } \\
\begin{array}{l}\text { C1q receptor complex) } \\
\text { gC1qbp }\end{array}\end{array}$ & $\begin{array}{l}\text { Binds C1q and other complement derived opsonins (C4b, C3b, iC 3b, MBL); involved in immune complex transfer } \\
\text { Cell surfeceptor for the collagenous domains of C1q; uptake of apoptotic cells, induction of chemotaxis }\end{array}$ \\
\hline
\end{tabular}

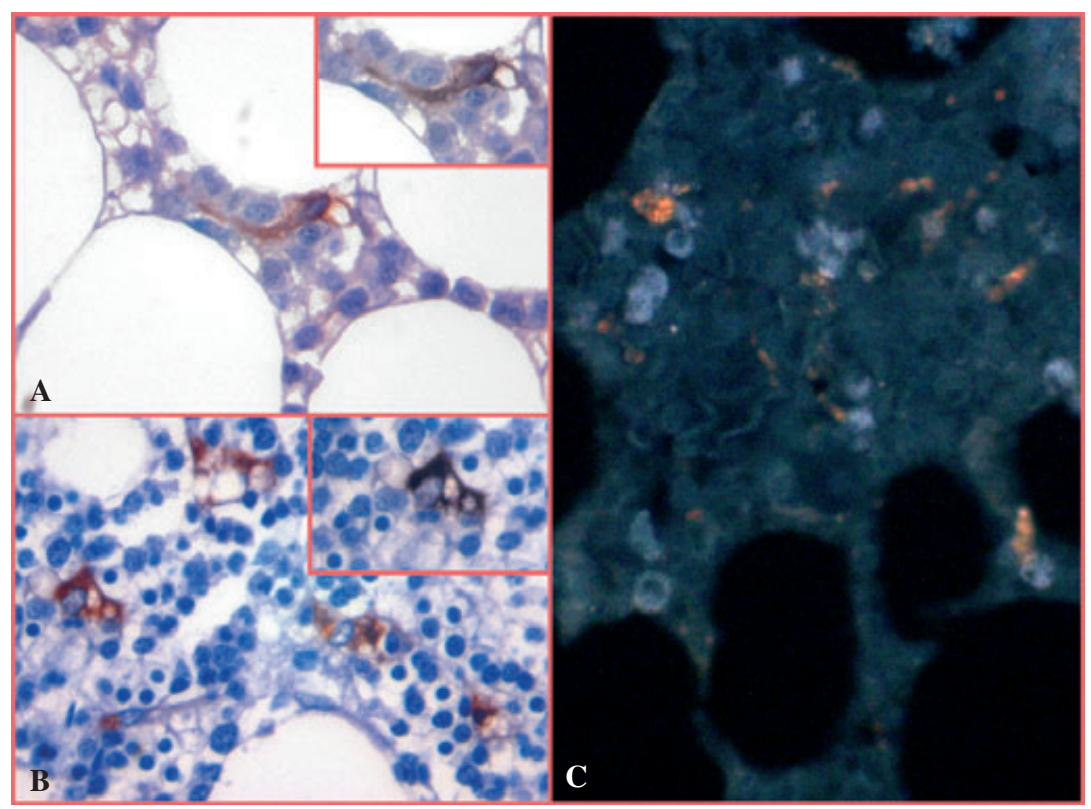

Figure 1 (A) The few bone marrow dendritic cells are positive to C1q (anti-C1q Dako, rabbit anti-human polyclonal antibody, 1:100; original magnification $400 \times)$. CD1a staining (inset) confirms their dendritic phenotype (anti-CD1a Dako, mouse anti-human monoclonal antibody, 1:50; original magnification $400 \times$ ). (B) $\mathrm{C} 1 \mathrm{q}$ is also expressed by bone marrow macrophages expressing CD68 (inset, anti-CD68 Dako, mouse anti-human monoclonal antibody, 1:50; original magnification $400 \times$ ). (C) The orange signal throughout the cytoplasm of bone marrow stromal cells represents $\mathrm{C} 1 \mathrm{q}$ B-chain mRNA expression (original magnification $400 \times$ ). 
finding, together with our observation of C1q production by bone marrow stromal cells, makes it possible to speculate on a role for $\mathrm{C} 1 \mathrm{q}$ in the maintenance of bone marrow homeostasis through an autocrine feedback system. These results may add a valuable piece of information to the current figure about the interactions between human bone marrow stroma and the complement system.

\section{References}

1 Bajtay Z, Csomor E, Sandor N, Erdei A. Expression and role of FCand complement-receptors on human dendritic cells. Immunol Lett 2006;104:46-52.

2 Rossi M, Young JW. Human dendritic cells: potent antigen-presenting cells at the crossroads of innate and adaptive immunity. J Immunol 2005;175:1373-81.

3 Nauta AJ, Castellano G, Xu W et al. Opsonization with C1q and mannose-binding lectin targets apoptotic cells to dendritic cells. J Immunol 2004;173:3044-50.
4 Castellano G, Woltman AM, Nauta AJ et al. Maturation of dendritic cells abrogates $\mathrm{C} 1 \mathrm{q}$ production in vivo and in vitro. Blood 2004;103:3813-20.

5 Wilson A, Trumpp A. Bone-marrow haematopoietic-stem-cell niches. Nat Rev Immunol 2006;6:93-106.

6 Foucar K. Non-Hodgkin lymphoma and Hodgkin lymphoma (disease) in bone marrow. In: Foucar K, ed. Bone Marrow Patbology, 2nd edn. Chicago, IL: ASCP Press, 2001:439-83.

7 Yamada M, Oritani K, Kaisho $\mathrm{T}$ et al. Complement C1q regulates LPS-induced cytokine production in bone marrow-derived dendritic cells. Eur J Immunol 2004;34:221-30.

C. Tripodo, R. Porcasi, C. Guarnotta, S. Ingrao, V. Campisi, A. M. Florena \& V. Franco

Dipartimento di Patologia Umana, Palermo, Italy.

Correspondence to: C. Tripodo. Dipartimento di Patologia Umana, via del Vespro, 129, 90100 Palermo, Italy. E-mail: tripodo@unipa.it 